(c) American Dairy Science Association, 2004.

\title{
Production and Health of Pasture-Fed Dairy Cattle Following Oral Treatment with the Ionophore Lasalocid
}

\author{
S. McDougall, L. Young, and F. M. Anniss \\ Animal Health Centre, Morrinsville, New Zealand
}

\section{ABSTRACT}

The aim of the study was to evaluate the effect of feeding the ionophore lasalocid on the productivity and health of seasonally calving, pasture-fed dairy cows. Dairy cows $(n=1020)$ from 4 herds were enrolled in a split-herd, prospective intervention study. Cows were blocked by breed and age, ranked on previous production, and then assigned to 2 treatment groups. Treatment cows were each exposed to 300 to $350 \mathrm{mg}$ of lasalocid/d commencing $3 \mathrm{wk}$ before and ending $18 \mathrm{wk}$ after the start of the seasonal calving period. Milk production was determined on 3 occasions for each cow at approximately monthly intervals (herd tests 1 to 3 ), body condition score was determined fortnightly, and all disease occurrences were recorded. Lasalocid treatment increased milk volume milk protein and milk fat production by $\sim 2 \%$, without altering milk composition. Fewer lasalocid-treated cows than control cows ( 7.3 vs. $11.6 \%$, respectively) were diagnosed with clinical mastitis. Lasalocid treatment of pasture-fed dairy cows resulted in reduced mastitis incidence and increased milk production without changes in body condition or negative effects on metabolic processes as monitored by metabolite concentrations.

(Key words: lasalocid, dairy cow, disease, milk production)

Abbreviation key: BUN = blood urea nitrogen, $\mathbf{M S}=$ milk solids, $\mathbf{N D E}=$ not detected in estrus, $\mathbf{S D E}=$ standard error of the difference.

\section{INTRODUCTION}

Ionophores are a group of polyether antibiotics that includes lasalocid and monensin. Ionophores alter bacterial flora of the rumen, leading to decreases in grampositive bacteria, protozoa, and fungi and increases in gram-negative bacteria. The net effect of these changes in bacterial flora is increased propionate production; a decrease in acetate, butyrate, and methane production;

Received September 1, 2003

Accepted May 7, 2004.

Corresponding author: S McDougall; e-mail: smcdoug@ahc.co.nz. increased DM digestibility; a protein-sparing effect (Hanson and Klopfenstein, 1979) with a resultant decrease in rumen ammonia concentration; and a decrease in ruminal lactate levels. Monensin sodium aids in controlling lactic acidosis and pasture bloat, and is antiketogenic (by increasing serum glucose and reducing serum BHBA; Sauer et al., 1989).

Lasalocid has been extensively used in beef cattle, but less so in the dairy industry. Variable feed intakes, milk production, and composition responses have been observed in 3 studies in which dairy cattle were fed lasalocid within a TMR (Johnson et al., 1988; Weiss and Amiet, 1990; Erasmus et al., 1999). In these studies, milk yield was either unaltered (Weiss and Amiet, 1990; Erasmus et al., 1999) or reduced (Johnson et al., 1988). Animal health outcomes were not evaluated in these studies.

In contrast, monensin has been extensively evaluated in lactating dairy cattle in both pasture- and TMR-fed dairy cattle. Increases in milk volume of between 2 and $8 \%$ have been reported following use of monensin in dairy cattle (Lynch et al., 1990; Lowe et al., 1991). Milk composition has been unaltered in some studies (Duffield et al., 1999b), whereas milk fat concentration was depressed in others (Hayes et al., 1996; Van der Werf et al., 1998). Animal health benefits have been demonstrated following monensin treatment in some, but not all, studies. $\beta$-Hydroxybutyrate concentrations are lower in monensin-treated vs. control cows (Sauer et al., 1989; Duffield et al., 1998b). Serum glucose concentrations have been shown to be higher with monensin treatment (Abe et al., 1994; Duffield et al., 1998b). Field trials with monensin have demonstrated a reduced prevalence of clinical ketosis and of multiple diseases as well as a decreased probability of being culled in the first 3 mo of lactation (Duffield et al., 1999b). A reduction in clinical and subclinical mastitis incidence, a reduction in lameness incidence, and shorter calving-tofirst-estrus intervals and calving-to-conception intervals in cows previously diagnosed with endometritis have also been reported following monensin treatment (Heuer et al., 2001).

This study was undertaken to evaluate the effects of lasalocid on milk yield and composition, BCS, and ani- 
mal health in pasture based production systems. Production effects of lasalocid in pasture-fed dairy cattle and the effect of lasalocid on the health of dairy cattle have not been previously evaluated. Although the related ionophore, monensin, has been extensively evaluated, no direct comparisons of monensin with lasalocid have been undertaken; therefore, it cannot be assumed that the 2 ionophores have the same effects.

\section{MATERIALS AND METHODS}

Cows from 4 seasonal calving (July to September) pasture-, pasture silage-, and hay-fed dairy herds (average herd size $=312, \mathrm{SD}=91$, range $=181$ to $386 \mathrm{cows}$ ) from the Waikato region of New Zealand were enrolled. Herds were selected based on the availability of pregnancy diagnosis and herd production data from the previous lactation, routine use of oral drenching of trace element suspensions throughout the spring, and the willingness of owners to be involved in the trial.

The sample size was calculated using the computer program Pass 2000 (Hintze, 2001). Sample size calculations were based on a 5\% increase in milk solids (MS; e.g., fat and protein: $0.04 \mathrm{~kg}$ of MS/cow per day) with a type $1(\alpha)$ error of 0.05 and a type $2(\beta)$ error of $20 \%$, with a control level of production of $0.8 \mathrm{~kg}$ of MS/cow per day. A minimum sample size of 400 cows per treatment group was calculated. The number of cows enrolled for blood sampling for metabolite determination was based the assumption that the average serum BHBA concentrations of pasture-fed cows range between 0.5 to 1 $\mathrm{mmol} / \mathrm{L}$, with a standard deviation of approximately 0.2 to 0.5 units. To demonstrate a significant difference ( $\alpha=0.05,1-\beta=0.8$ ), where the standard deviation is $0.5 \mathrm{mmol} / \mathrm{L}$ and the observed difference required to be detected is $0.3 \mathrm{mmol} / \mathrm{L}, 45$ animals per treatment group were required.

Cows were randomly assigned to treatment within herds following blocking by breed (Friesian, Jersey, or Friesian-Jersey crossbred) and age code (2, 3, 4 to 8, and $9+\mathrm{yr}$ ), and then were ranked on MS production (i.e., fat + protein) for the previous lactation. Heifers (i.e., rising $2 \mathrm{yr}$ ) and 3-yr-old cows in herd $\mathrm{D}$ (which did not undertake production assessment in the previous season) were ranked on birth date and then randomly assigned within sequential pairs.

Animals in herds A, C, and D were weighed (to the nearest $0.5 \mathrm{~kg}$ ), body condition scored (on a 1 to 10 scale, with $1=$ thin $10=$ fat; Macdonald and Macmillan, 1993) and the withers height estimated by alignment with a scale mounted vertically within a race or crush approximately $3 \mathrm{wk}$ before the planned start of the calving period. The BCS score is approximately double that described for the 1 to 5 point scale described by
Edmonson et al., (1989). Neck collars color-coded for treatment group were applied at the commencement of the study. In herds A, C, and D, the treatment and control groups were managed in a series of separate paddocks before calving to facilitate feeding. The area of pasture offered was calculated on a daily basis such that the same area was offered to each cow in each group. The area ranged from 10 to $140 \mathrm{~m}^{2} /$ cow per day depending on level of supplementary hay or pasture silage feeding. The area offered was controlled by use of moveable electrical fencing. As cows calved and entered the milking herd, the number of animals left in the nonlactating groups reduced so that the area/group was reduced accordingly.

Before calving, each cow in herds A, C, and D was fed pasture hay $(0.5 \mathrm{~kg}$ of $\mathrm{DM} / \mathrm{d})$ with a suspension of $60 \mathrm{~g}$ of magnesium oxide mixed in $30 \mathrm{~mL}$ of molasses and made up to a total volume of $150 \mathrm{~mL}$ with water. The treated group was offered the same suspension, but with each cow receiving an additional $350 \mathrm{mg}$ of lasalocid/d (as a 1\% solution prepared from $20 \%$ lasalocid [Bovatec 20 liquid, Alpharma Ltd., Auckland, New Zealand] diluted in $1 \%$ monopropylene glycol with $0.5 \%$ xanthan gum by Jaychem Industries, Auckland, New Zealand). The volume of suspension was modified twice weekly to adjust for cows calving in each group.

The amount of pasture consumed by the treatment and control groups was estimated 2 and 4 wk after commencement of treatment of herds A, C, and D. The physical area offered for grazing (ha) was estimated by pacing the pasture area, the amount of pasture present immediately before (pasture mass pre ) and after grazing (pasture mass post $_{\text {; }}$ as $\mathrm{kg}$ of $\mathrm{DM} / \mathrm{ha}$ ) was estimated with a rising plate meter, and the number of cattle in the group was counted. From these data, the mass of pasture (kg of DM/cow per day) that was consumed was estimated as:

$$
\begin{aligned}
& \text { DM consumed }= \\
& {\left[\left(\text { pasture } \text { mass }_{\text {pre }}-\text { pasture mass } \text { post }\right) \times \text { area }\right] / \text { no. cows }}
\end{aligned}
$$

A pasture sample was collected from a paddock before grazing by the control and treated group on one occasion within 2 wk of treatment commencement for each herd (A, C, and D). Additionally, a composite sample of the hay fed to the herds was taken. These samples were then submitted for near infrared spectroscopy (Alpha Scientific, Hamilton, New Zealand), from which the $\mathrm{DM}, \mathrm{OM}, \mathrm{CP}, \mathrm{ADF}, \mathrm{NDF}$, digestibility, and metabolizable energy were estimated.

All cows in herd B were managed as a single group before and after calving, and the cows were brought to the dairy parlor daily to be orally drenched with 300 $\mathrm{mg}$ of lasalocid (as a 1\% solution). 
Following calving, the treatment group in all herds was drenched once daily orally with $300 \mathrm{mg}$ of lasalocid (as a 1\% solution) by the herd owners or staff. The color neckbands were used as the basis for the treatment, so the study was not blinded. Additionally, all cows in all herds were drenched once daily with an oral suspension containing magnesium oxide (20 to $60 \mathrm{~g}$ ), sodium chloride (10 to $20 \mathrm{~g}$ ), calcium carbonate ( 0 to $70 \mathrm{~g}$ ), copper sulfate ( 0 to $2 \mathrm{~g}$ ) and pluronic ethoxylated nonionic detergents ( 0 to $15 \mathrm{~mL}$ ) to aid in control of frothy bloat.

Twenty pairs of treated and control animals were randomly selected from each herd following blocking for breed and age for blood sampling and BCS at fortnightly intervals commencing $3 \mathrm{wk}$ before the planned start of calving through $\sim 18 \mathrm{wk}$ after the planned start of calving. Blood samples $(10 \mathrm{~mL})$ were collected by venipuncture from the tail vein into plain and fluoroxidase-containing evacuated glass vials (Vacutainer, Becton Dickinson, Franklin Lakes, NJ). Blood sampling occurred between 1500 and $1700 \mathrm{~h}$ to minimize the reported within-day variation in BHBA, glucose, and NEFA concentrations (Kolver and Macmillan, 1994). Samples from all herds were transported in foam insulated containers and then stored at $4^{\circ} \mathrm{C}$ until centrifuged within $14 \mathrm{~h}$ of collection. The supernatant was stored at $-20^{\circ} \mathrm{C}$ before analysis of BHBA, NEFA, blood urea nitrogen (BUN), and glucose concentrations. Variation in serum constituent concentration is less than $10 \%$ following up to $24 \mathrm{~h}$ of storage on the clot at $4^{\circ} \mathrm{C}$ for BHBA, BUN, glucose, and NEFA (Rosenberger, 1979).

\section{Laboratory Procedures}

Biochemical tests were performed using an Hitachi 717 (Roche) at an assay temperature of $30^{\circ} \mathrm{C}$. Concentrations of glucose in plasma were determined using the hexokinase method (TM Glucoquant, Boehringer Mannheim, Lewes, UK); NEFA in sera was determined using a colorimetric method based on the reaction of ATP and coenzyme A with NEFA (Wako, Fukuoka, Japan); BUN was measured using a kinetic UV test measuring conversion of urea to ammonia and then $\mathrm{NADH}$ to NAD; and BHBA in sera was measured following conversion of BHBA to acetoacetate, which in turn converts NAD to NADH. All analyses were performed over $5 \mathrm{~d}$, and the between-run coefficient of variation was $<5 \%$ for BHBA, BUN, and glucose, and $<8 \%$ for NEFA.

Milk production recording ("herd testing") occurred on average 6,11 , and $16 \mathrm{wk}$ after the planned start of calving for each herd. Milk sample meters were placed in the long milk line, and a subsample of milk was collected into a vial. The subsample was analyzed for milk fat and protein concentration and SCC at Live- stock Improvement Corp., Hamilton, New Zealand (herds A, B, and D) or South Auckland Independent Testing Laboratory, Hamilton, New Zealand (herd C) using infrared analysis (Fossomatic FC and Milkoscan FT 6000, Foss A/S, Hillerød, Denmark).

All animals were observed by the herd owners or staff at least daily in the nonlactating period and twice daily following calving for presence of disease from $3 \mathrm{wk}$ before to $18 \mathrm{wk}$ after the planned start of calving. Diseases were categorized and recorded as clinical mastitis (e.g., gross clots or wateriness of milk and/or swelling or heat of the udder), lameness (including interdigital necrobacillosis, white line disease, sole bruising; Weaver et al., 1981), reproductive disorders (e.g., retained fetal membranes, endometritis), hypocalcaemia, and "other" (e.g., trauma, undefined "ill" cows, Johne's disease, or subclinical mastitis [i.e., a cow with a individual SCC $>500$, which the herd owner treated with antibiotics]). Paint was applied to the tail head to aid in estrus detection approximately $4 \mathrm{wk}$ before the planned start of the seasonal breeding program. Herd managers were responsible for estrus detection. Cows were categorized as not detected in estrus (NDE) if the tail paint was intact $7 \mathrm{~d}$ before the start of the seasonal breeding program. All such cows were submitted for veterinary examination. Those found not to have palpable corpus luteum were treated with an intravaginal progesteronereleasing device for 6 to $8 \mathrm{~d}$ (CIDR Cattle Insert, Pfizer Animal Health, Manukau City, New Zealand) with an injection of $1 \mathrm{mg}$ of estradiol benzoate (CIDIROL injection, Bomac Laboratories, Manukau City, New Zealand) $1 \mathrm{~d}$ after device removal (Rhodes et al., 2003).

\section{Statistical Analysis}

The pretreatment withers height, BCS or live weight, and age and calving date for the lasalocid and control groups were compared by ANOVA, with herd and treatment group as the main effects.

Pasture consumption (i.e., kg of DM/cow per day) was analyzed using a univariate GLM with herd $(\mathrm{df}=3)$, group (treated or control; $\mathrm{df}=1$ ), and week (wk 2 or 4 after treatment commenced; $\mathrm{df}=2$ ) as main effects.

The metabolic variables (BHBA, glucose, NEFA, and BUN) and BCS were analyzed using repeated-measures ANOVA with treatment (lasalocid vs. control), age code (2 and 3 or $>3 \mathrm{yr}$ ), and herd (A, B, C, D) as the main (fixed) effects, and interval between commencement of treatment and calving date (as weeks) included as the covariate. The data were aligned by calving date such that the first sample collected following calving was assigned as wk 0. As the BHBA and NEFA were not 
normally distributed, they were $\log _{10}$ transformed before analysis. A model with all main effects and the interactions of treatment $\times$ age, treatment $\times$ herd, and treatment $\times$ interval between commencement of treatment and calving was initially constructed. Nonsignificant (i.e., $P>0.05$ ) interactions were then removed, so the final model included all interactions that were significant $(P<0.05)$ and all main effects whether significant or not. Both the within-subjects effects (i.e., time $\times$ other main effects) and the between-subjects effects were evaluated. As Mauchly's test of sphericity was invariably significant, indicating that the variancecovariance matrices were not circular, the GreenhouseGeiser adjustment was used for hypothesis testing. The validity of the models was tested by examining a histogram of the studentized residuals over which a normal curve had been superimposed and by plotting the studentized residuals (y-axis) against the expected value (x-axis) and examining the variance across the range of expected values. For BUN, the pretreatment concentration differed between treatment and control groups $(P<0.05)$. However, once the data were aligned by calving date, no such difference existed. Hence, the pretreatment BUN concentration was not included as a covariate within the final BUN model. Where herd $x$ time $\times$ treatment interactions were found, specific hypothesis testing of the effect of treatment within a herd and at a selected time points was undertaken by calculating the standard error of the difference (SED) and declaring a difference $(P<0.05)$ where the estimated marginal means were more than twice the SED.

Milk production (MS, kg/cow per day), protein ( $\mathrm{kg} /$ cow per day and \%), milk fat (kg/cow per day and \%), and the individual cow log 10 somatic cell counts were analyzed by repeated-measures analyses using a generalized linear model with herd, age code (i.e., 2, 3, 4 to 8 and $9+$ yr old), and treatment as fixed effects, and DIM at the test as a covariate. Initially models with all main effects and interactions were tested. Nonsignificant interactions were then sequentially removed until only those interactions that were significant (i.e., $P<0.05)$ and the main effects were still present. Data are presented as estimated marginal means and the SED unless otherwise stated. Cows that had not calved by the first milk production assessment (herd test) were lost from analysis, as were a small number of cows that had incomplete milk production records. Similar numbers of cows were excluded from each group (i.e., $66 / 505$ or $13.1 \%$ and $63 / 494$ or $12.8 \%$ of controls and lasalocid-treated cows, respectively).

The cumulative incidence rate for clinical mastitis over the period of enrollment (i.e., from 3 wk before to $\sim 18$ wk after the start of the seasonal calving period for each herd) was analyzed with a forward stepwise logistic regression model with the main effects offered including treatment (i.e., lasalocid vs. no treatment), age code $(2,3,4$ to 8 , or $9+\mathrm{yr})$, and herd. First-order interactions of the main effects were tested and found to be nonsignificant $(P>0.2)$. The validity of the model was tested by assessing the Hosmer-Lemeshow test $(P=$ 0.47 , and the number of residuals that were outliers (i.e., $>2 \mathrm{SD}$ of observed from expected values for each case) was 41 of 1020 (4\%) cases. The number of cases of other the disease categories were too small for statistical analyses.

The proportion of NDE cows was analyzed with a logistic regression model as described above, with herd and treatment as the main fixed effects within the model.

All statistical procedures were performed using SPSS 11.5.1 (Chicago, IL). This study was approved by the Animal Ethics Committee of AgResearch, Ruakura, Hamilton, New Zealand.

\section{RESULTS}

\section{Balance of Treatment Groups}

There were no differences between the lasalocid and control groups in pretreatment wither height $(P=0.57)$, BCS $(P=0.92)$, live weight $(P=0.85)$, age $(P=0.49)$, calving date $(P=0.84)$, pretreatment $\log _{10}$ BHBA $(P=$ $0.71), \log _{10}$ NEFA $(P=0.60)$, and glucose $(P=0.68)$. However, the control group had a lower BUN concentration than the lasalocid group pretreatment $(7.5 \pm 0.2$ vs. $8.0 \pm 0.1$ mean \pm SEM for control vs. lasalocid, respectively; $P=0.04$ ).

\section{Cows Lost to Follow Up}

A total of 63 cows (5.9\% of the initial 1062 cows) were lost to follow up. There was no difference in the loss rate between treated $(36 / 530,6.8 \%)$ and control groups $(27 / 532,5.1 \% ; P=0.2)$. These losses were in herd A ( 45 cows), herd $\mathrm{C}$ (9 cows), and herd D (9 cows). In herd A, a number of cows (39) failed to calve within 2 wk of due date and were removed from treatment and analysis. Other losses to follow up included abortion (1), calved before study commenced (1), failed to calve and not pregnant (1), culled before completion of the trial (3; all control group), and failure to yard for weighing or blood sampling as required (6; 2 from control group, 4 from lasalocid group). A total of 12 cows died during the study. Reasons for loss include bloat (3; all in control group), trauma (6; hit by tree, fell, etc.; 3 from each group), and infectious diseases ( $3 ; 2$ from control group, 1 from lasalocid group). 
Table 1. Assessment of pasture and hay fed precalving to cows from 3 herds (A, C, D) in which cows were randomized to treatment groups (lasalocid or control) before calving and group fed.

\begin{tabular}{lllllllllll}
\hline Herd & Sample & Group & $\begin{array}{l}\mathrm{DM} \\
(\mathrm{g} / \mathrm{kg})\end{array}$ & $\begin{array}{l}\mathrm{OM} \\
(\mathrm{g} / \mathrm{kg})\end{array}$ & $\begin{array}{l}\mathrm{CP} \\
(\mathrm{g} / \mathrm{kg})\end{array}$ & $\begin{array}{l}\mathrm{ADF} \\
(\mathrm{g} / \mathrm{kg})\end{array}$ & $\begin{array}{l}\mathrm{NDF} \\
(\mathrm{g} / \mathrm{kg})\end{array}$ & $\begin{array}{l}\mathrm{sol} \mathrm{CHO}^{1} \\
(\mathrm{~g} / \mathrm{kg})\end{array}$ & $\begin{array}{l}\mathrm{Dig} \mathrm{OM}^{2} \\
(\mathrm{~g} / \mathrm{kg})\end{array}$ & $\begin{array}{l}\mathrm{ME}^{3} \\
(\mathrm{MJ} / \mathrm{kg})\end{array}$ \\
\hline A & Hay & Both & 860 & 915 & 115 & 418 & 706 & & 440 & 7.1 \\
$\mathrm{C}, \mathrm{D}$ & Hay & Both & 756 & 912 & 129 & 396 & 577 & & 479 & 7.7 \\
$\mathrm{~A}$ & Pasture & Control & 158 & 887 & 231 & 229 & 490 & 122 & 769 & 12.3 \\
$\mathrm{~A}$ & Pasture & Lasalocid & 176 & 886 & 269 & 216 & 457 & 101 & 769 & 12.3 \\
$\mathrm{C}$ & Pasture & Control & 200 & 882 & 214 & 236 & 483 & 135 & 752 & 12.0 \\
$\mathrm{C}$ & Pasture & Lasalocid & 189 & 898 & 227 & 219 & 490 & 131 & 755 & 12.1 \\
$\mathrm{D}$ & Pasture & Control & 218 & 908 & 190 & 228 & 500 & 146 & 768 & 12.3 \\
$\mathrm{D}$ & Pasture & Lasalocid & 223 & 917 & 173 & 204 & 461 & 197 & 815 & 13.0 \\
$P_{\text {herd }}{ }_{4}$ & & & 0.07 & 0.08 & 0.14 & 0.19 & 0.79 & 0.28 & 0.32 & 0.28 \\
$P_{\text {treat }}{ }_{4}$ & & & 0.68 & 0.25 & 0.55 & 0.03 & 0.27 & 0.73 & 0.39 & 0.35 \\
\hline
\end{tabular}

${ }^{1}$ Soluble carbohydrate.

${ }^{2}$ Digestibility of the OM.

${ }^{3}$ Metabolizable energy.

${ }^{4}$ The probability of a difference in feed composition between herds $\left(P_{\text {herd }}\right)$ and treatments $\left(P_{\text {treat }}\right)$.

\section{Pasture Intake and Quality Precalving}

There was no difference in estimated precalving pasture intake for the lasalocid and control groups (6.6 vs. 6.4 $\mathrm{SED}=0.6 \mathrm{~kg}$ of $\mathrm{DM} / \mathrm{cow}$ per day for the treated and lasalocid groups, respectively; $P=0.80$ ) or between weeks ( 5.9 vs. $7.1 \mathrm{SED}=0.6$ for wk 2 and 4 , respectively; $P=0.18)$. However, there were significant differences among herds in pasture consumed ( 4.9 vs. 5.8 vs. 8.6 $\mathrm{SED}=0.7 \mathrm{~kg}$ of $\mathrm{DM} / \mathrm{cow}$ per day for herds $\mathrm{A}, \mathrm{C}$, and $\mathrm{D}$, respectively; $P=0.02$ ).

The DM and OM proportion in pasture offered to cows before calving tended to vary among herds $(P=$ 0.07 and $P=0.08$, respectively; Table 1 ), whereas the $\mathrm{ADF}$ was lower in the lasalocid vs. the control group pasture (213 vs. $231, \mathrm{SED}=2.3 \mathrm{~g} / \mathrm{kg}$ of DM ADF for lasalocid vs. control pasture, respectively; $P=0.03$ ).

\section{Blood Metabolites}

The overall $\log _{10}$ BHBA concentrations did not differ between treatments $(P=0.56)$. However, there were treatment $\times$ time $(P=0.009)$, herd $\times$ time $(P=0.001)$, and herd $\times$ treatment $\times$ time interactions $(P=0.02)$, whereby in some herds, and at some time points, there were significant differences between the lasalocid and control groups (Figure 1). The glucose and $\log _{10}$ NEFA concentrations did not differ between treatments $(2.85$ vs. $2.82[\mathrm{SED}=0.03] \mathrm{mmol} / \mathrm{L}$ for glucose, and -0.66 vs. $-0.67[\mathrm{SED}=0.02] \mathrm{mmol} / \mathrm{L}$ for $\log _{10} \mathrm{NEFA}$ for lasalocidtreated vs. control cows, respectively; $P=0.25$ and $P=$ 0.38 ). Blood urea nitrogen concentration was higher in lasalocid vs. control group cows $(7.9$ vs. 7.6 [SED = $0.13 \mathrm{mmol} / \mathrm{L}$ for lasalocid-treated vs. control groups, respectively, $P=0.008$ ). Blood urea nitrogen concentration varied among herds $(P<0.001)$, changed over time
$(P<0.001)$, varied between herds across time $(P<$ $0.001)$, and varied between the treatments across time $(P=0.08$; Figure 2).

\section{Fortnightly BCS}

Body condition score did not differ between the lasalocid and control cows (4.65 vs. 4.64 [SED $=0.06$ ]; $P=$ $0.87)$ nor did the treatments differ across time $(P=$ $0.23)$. The BCS declined with time $(P<0.01)$ and varied among herds across time $(P<0.01)$.

\section{Milk Production}

Treatment increased, or tended to increase, the milk volume, MS, milk protein and milk fat production (Table 2). However, the milk protein and milk fat percentages were unaffected by treatment (Table 2). There were no treatment $\times$ herd, treatment $\times$ age, or treatment $\times$ time interactions for any of these variables (all $P$ $>0.2$ ).

\section{Disease Diagnosis}

The cumulative incidence rate of all diseases was $15.7 \%$ over the study period. There were $97,18,15,18$, and 12 cows diagnosed with clinical mastitis, reproductive disease, lameness, hypocalcemia, and "other" diseases over the study period, respectively. The majority of disease diagnosis occurred peripartum, with the average interval from calving to diagnosis being $9.0(\mathrm{SD}=$ $27.2) \mathrm{d}$. There was no difference between lasalocid and control cows in the interval from calving to first disease diagnosis $(P=0.3)$. Lasalocid treatment was associated with a lower cumulative incidence of clinical mastitis (37/504 or $7.3 \%$ vs. $60 / 516$ or $11.6 \%$ ) for lasalocid vs. 

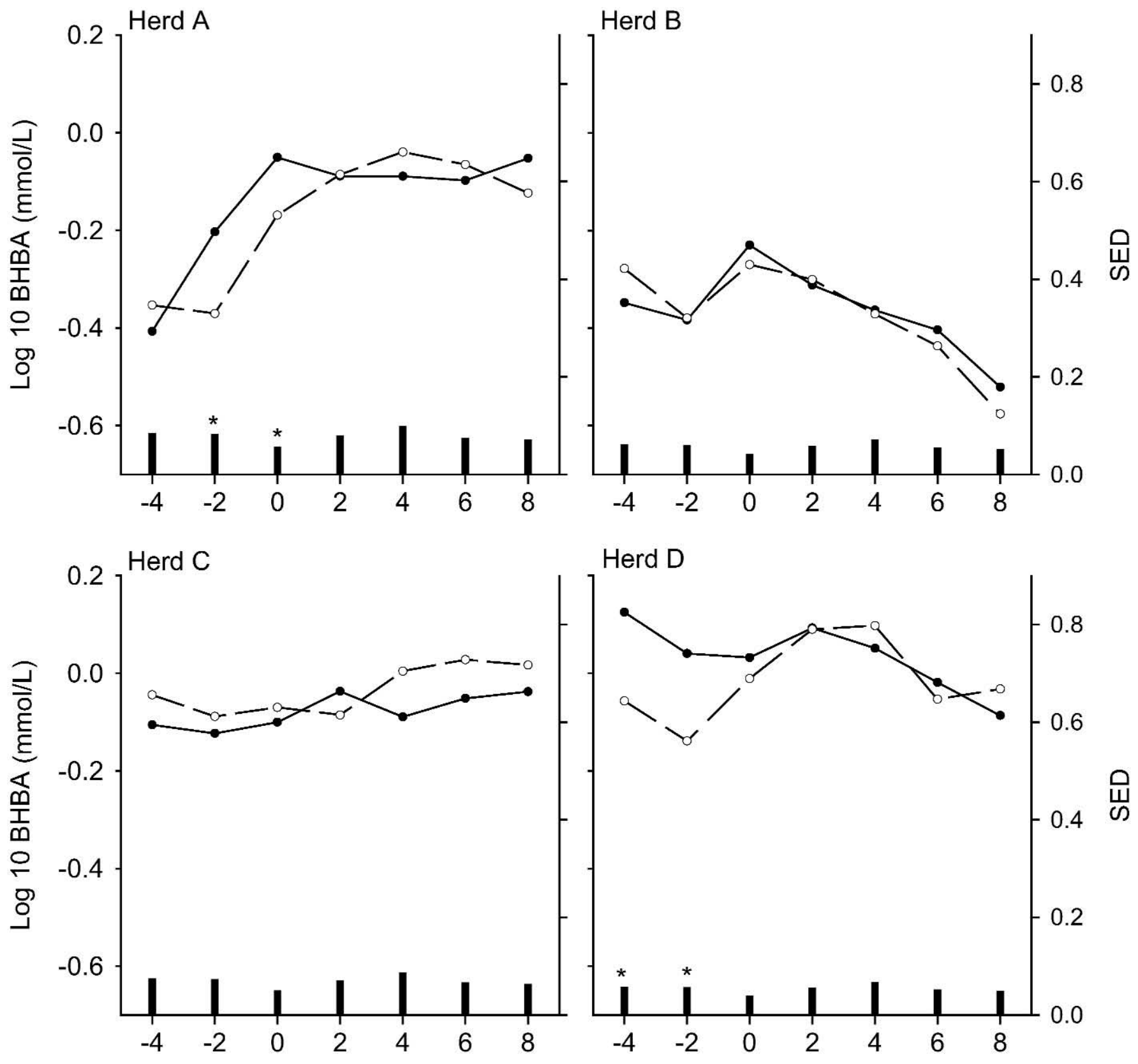

Weeks relative to calving

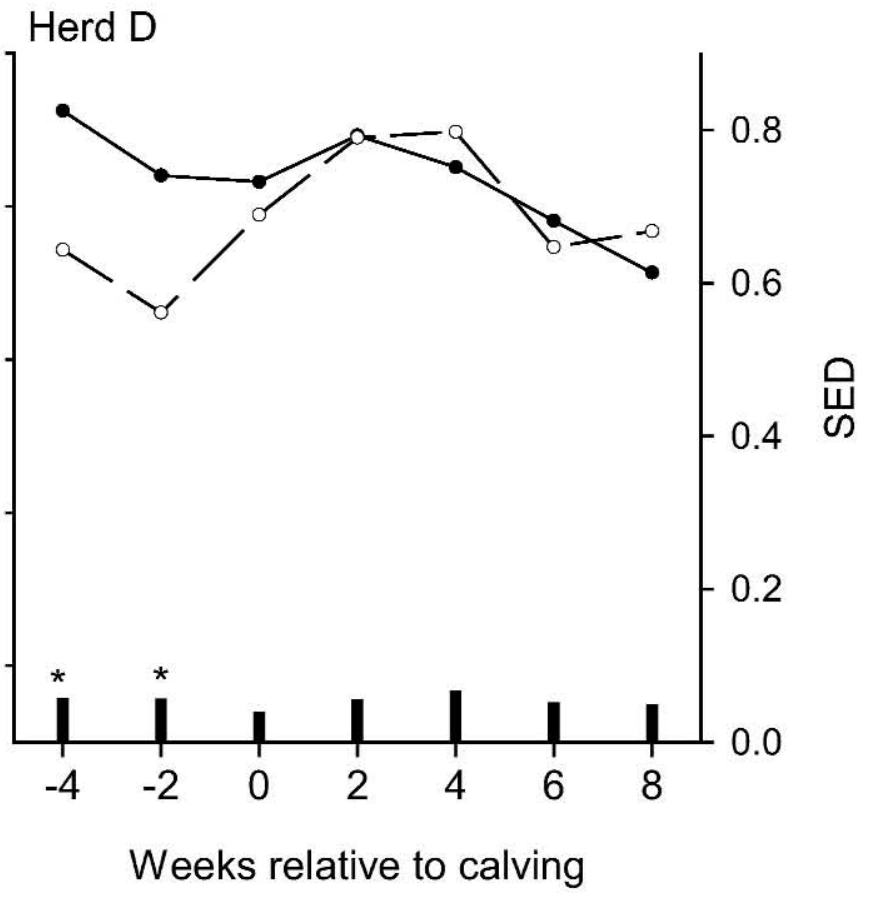

Figure 1. The fortnightly estimated marginal mean and standard error of the difference (SED) $\log _{10}$ BHBA concentration for cows treated with lasalocid (-O-) or left as untreated controls (-) from 4 dairy herds. *Indicates differences between treatment and control $(P<0.05)$.

control, respectively, $P=0.02$ ). The incidence rate of clinical mastitis tended to vary among herds (range $=$ 6.1 to $12.1 \% ; P=0.08$ ) and was lower in 3 -yr-old cows than other age groups $(30 / 214$ or $14 \%, 8 / 164$ or $4.9 \%$, $51 / 579$ or $8.8 \%$, and $7 / 62$ or $11.3 \%$ for $2,3,4$ to 8 , and 9+-yr-old cows respectively; $P=0.03$ ).

\section{Proportion of Cows Not Detected in Estrus}

The proportion of the herd that was NDE by the commencement of the seasonal mating period was affected by herd $(P<0.01)$, and there was a herd $\times$ treatment interaction $(P=0.06$; Table 3$)$ whereby in herd $\mathrm{C}$, 


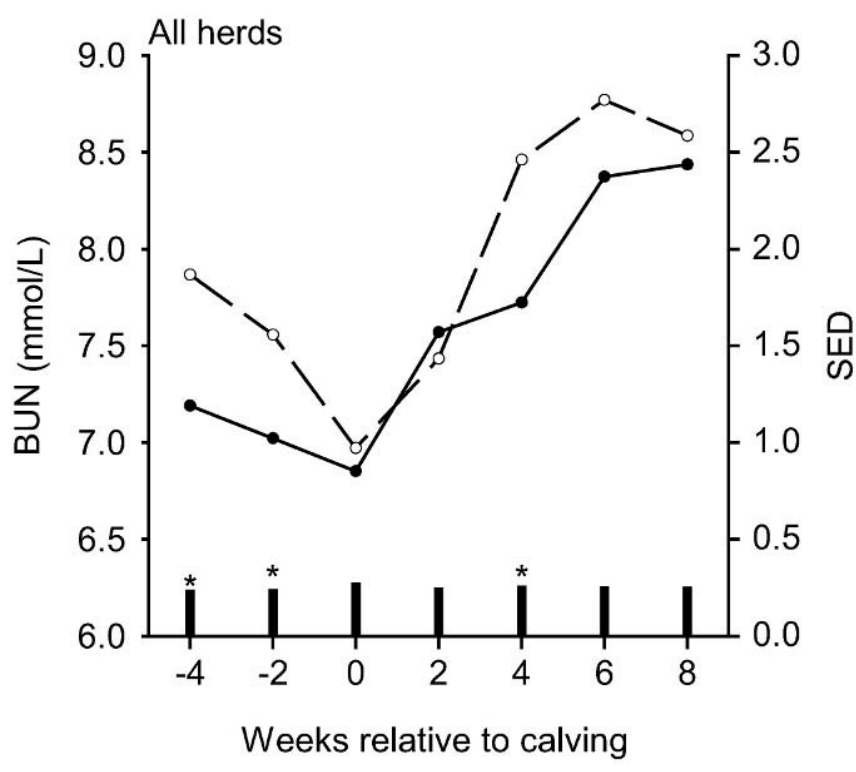

Figure 2. The fortnightly estimated marginal mean and standard error of the difference (SED) for blood urea nitrogen (BUN) concentration of cows treated with lasalocid (-O-) or left as untreated controls (-) from 4 dairy herds. *Indicates differences between treatment and control $(P<0.05)$

treatment with lasalocid was associated with a reduced risk of NDE diagnosis compared with controls (relative risk $=0.41,95 \%$ confidence interval $=0.24$ to $0.84 ; P$ $<0.05)$.

\section{DISCUSSION}

The treatment and control groups were balanced for withers height, age, BCS, calving date, and age, indicating that the randomization procedures resulted in balanced groups. Cows were group-fed before calving in 3 of the 4 herds; thus, the absolute amount of lasalocid consumed by individual cows in these herds cannot be determined. It is likely that there would have been some
Table 3. The number (and \%) of cows within 4 herds not detected in estrus (NDE) by $1 \mathrm{wk}$ before the start of the seasonal breeding program for cows treated lasalocid or left as untreated controls.

\begin{tabular}{lccc}
\hline Item & Control & Lasalocid & Total \\
\hline Herd A & & & \\
NDE & 17 & 10 & 27 \\
Total & 85 & 72 & 157 \\
\% NDE & 20.0 & 13.9 & 17.2 \\
Herd B & & & \\
NDE & 33 & 41 & 74 \\
Total & 178 & 180 & 358 \\
\% NDE & 18.5 & 22.8 & 20.7 \\
Herd C & & & 48 \\
NDE & 32 & 16 & 183 \\
Total & 93 & 90 & 26.2 \\
\% NDE & 34.4 & 17.8 & 36 \\
Herd D & & 15 & 322 \\
NDE & 21 & 162 & 11.2 \\
Total & 160 & 9.3 & \\
$\%$ NDE & 13.1 & &
\end{tabular}

variation in daily intake among cows and potentially between treatment and control groups. However, no difference in the quantity or in most quality measures of pasture and hay offered before calving were found between lasalocid and control groups. Additionally, cows in the fourth herd (herd B) were orally dosed individually on a daily basis throughout the study. The results from this herd do not differ markedly from the other herds in the study. Hence, it unlikely that the conclusions of the study would be different if individual cow oral treatment were used rather than group feeding precalving.

The majority of cows undergo a period of "negative nutrient balance," where nutrient intake does not meet nutrient demands of production after calving and body tissue is mobilized (Bauman and Currie, 1980). Hence, metabolite concentrations and BCS were measured to assess the type and degree of body tissue mobilization. The amount of tissue mobilized, the relative proportion of lipid compared with muscle tissue mobilized, and the partitioning of this mobilized material to production is

Table 2. Estimated marginal means and standard error of the difference (SED) for production variables (per cow, per day) for cows from 4 herds treated orally with lasalocid or left as untreated controls.

\begin{tabular}{|c|c|c|c|c|c|c|c|c|}
\hline \multirow[b]{2}{*}{ Variable } & \multirow[b]{2}{*}{ Control } & \multirow[b]{2}{*}{ Lasalocid } & \multirow[b]{2}{*}{ SED } & \multicolumn{4}{|c|}{ Between subject $P$-values ${ }^{1}$} & \multirow{2}{*}{$\begin{array}{l}P \text {-values } \\
\text { within subject }{ }^{1} \\
\text { Time } \times R x\end{array}$} \\
\hline & & & & $\mathrm{Rx}^{2}$ & Herd & Age & Herd $\times$ Age & \\
\hline Volume (L) & 19.048 & 19.473 & 0.216 & 0.050 & 0.001 & 0.001 & 0.001 & 0.173 \\
\hline Milk solids (kg) & 1.562 & 1.591 & 0.015 & 0.055 & 0.001 & 0.001 & 0.001 & 0.340 \\
\hline Protein (kg) & 0.696 & 0.709 & 0.007 & 0.062 & 0.001 & 0.001 & 0.01 & 0.300 \\
\hline Milk fat $(\mathrm{kg})$ & 0.866 & 0.882 & 0.009 & 0.077 & 0.001 & 0.001 & 0.001 & 0.447 \\
\hline Protein $(\%)$ & 3.667 & 3.655 & 0.018 & 0.490 & 0.001 & 0.021 & 0.001 & 0.587 \\
\hline Milk fat (\%) & 4.594 & 4.583 & 0.039 & 0.780 & 0.001 & 0.493 & 0.261 & 0.580 \\
\hline $\log _{10} \operatorname{SCC}(\times 1000)$ & 1.717 & 1.730 & 0.025 & 0.607 & 0.012 & 0.001 & 0.376 & 0.346 \\
\hline
\end{tabular}

${ }^{1}$ Significance in the final repeated measures general linear model.

${ }^{2} \mathrm{Rx}=$ Treatment. 
under complex metabolic control and is influenced by dietary intake, stage of lactation, genetics, and initial body composition (Bauman and Currie, 1980; Broster et al., 1993). Body condition score declined across time in the current study and the decline was similar between lasalocid-treated and control cows.

Serum BHBA concentrations are reduced following monensin treatment (Sauer et al., 1989). Ionophores reduce the ruminal production of the BHBA precursor, butyrate, and increase proprionate production, thus providing increased gluconeogenic precursors that in turn may reduce demands for lipid mobilization and BHBA production. In the present study, the BHBA response was variable, with a reduction in BHBA in 2 herds (herds A and D) at 2 and 4 wk after treatment commencement, but no treatment effect with time in the other 2 herds. The between-herd variation likely reflects differences in herd level management of nutrition. In pasture-based production systems, the quantity and quality of feed offered varies over time due to changes in climatic conditions affecting pasture growth, but also due to the frequency with which the pasture is grazed. Significant variation occurs between farms and between seasons in pasture energy, protein, fiber, and macro- and micronutrient concentrations (Stevenson et al., 2003). The limited nutritional data collected in this study demonstrated that between-herd differences in pasture consumed and in quality did occur precalving. It is likely that differences in pasture quantity and quality between herds would have continued during postpartum periods as well, and that those differences may account for some of the herd $\times$ treatment interactions observed in the BHBA. Glucose concentrations were similar in the lasalocid-treated and control cows in the present study. Glucose concentrations have been unaltered (Sauer et al., 1989; Hayes et al., 1996) and increased (Abe et al., 1994; Duffield et al., 1998a) when assessed postpartum, and have been decreased prepartum (Stephenson et al., 1997) following pre(Sauer et al., 1989) or post- (Abe et al., 1994) partum commencement of monensin treatment. Blood urea nitrogen concentrations were higher pre- and postcalving, but were similar around calving for lasalocid-treated vs. control cows in the present study. Blood urea nitrogen concentrations reflect dietary intake of protein and nonprotein nitrogen, body catabolism, and urinary excretion of urea (Gordon and McMurray, 1979). Monensin reduces ammonia concentration within the rumen due to reduced intraruminal protein degradation and hence has a protein "sparing" effect in the rumen (Bergen and Bates, 1984). Increased protein flows to the small intestine may result in increased deamination, and hence elevated BUN concentrations (Hanson and Klopfenstein, 1979; Poos et al., 1979). However, as iono- phores increase proprionate production, there may be less catabolism of muscle tissue required to meet demands in early lactation with a resultant reduced BUN. Previous studies have demonstrated no effect on BUN (Abe et al., 1994) or an elevated BUN concentration (Poos et al., 1979) following monensin treatment, but did show a decreased milk urea nitrogen concentration following lasalocid treatment (Erasmus et al., 1999). The biological significance of the differences between treatments in the present study in BUN is not clear. However, there is a metabolic cost associated with producing urea (McBride and Kelly, 1990; Lobley et al., 1995).

Lasalocid treatment increased, or tended to increase, the milk volume, MS, milk protein, and milk fat production in the present study. The increases were small (i.e., approximately $2 \%$ ). Monensin treatment has been associated with increased production in a number of studies (Lowe et al., 1991; Hayes et al., 1996), whereas lasalocid has been previously associated with no change (Weiss and Amiet, 1990; Erasmus et al., 1999) or reduced (Johnson et al., 1988) milk production. Percentages of protein and milk fat were not affected by treatment in the present study. In contrast, a depression in milk fat concentration has been reported in some (Johnson et al., 1988; Lowe et al., 1991), but not all (Weiss and Amiet, 1990; Beckett et al., 1998), previous ionophore studies. The concentration of milk protein was not altered by monensin or lasalocid treatment in previous studies (Weiss and Amiet, 1990). Previous studies have found that genetic potential, breed (Johnson et al., 1988; Van der Werf et al., 1998), and BCS at commencement of treatment (Duffield et al., 1999a) modulate the production response to ionophores. In the current study, the increase in production occurred without significantly altering fortnightly BCS relative to control cows. That is, the increased production occurred without significantly increasing mobilization of body tissue.

The cost benefit of the increase in production and reduced mastitis incidence has not been fully evaluated for the current study. However, for a 300-cow herd, producing an average of $1.6 \mathrm{~kg}$ of MS (i.e., fat + protein)/ (cow·day), at a gross return of NZ $\$ 3.60 / \mathrm{kg} \mathrm{MS}$, the gross extra income is approximately NZ $\$ 26 / \mathrm{d}$, or NZ $\$ 2,600$ if treatment continued for $100 \mathrm{~d}$. If clinical mastitis costs the producer approximately NZ $\$ 100$ per case, and the incidence rate is reduced by $4 \%$, the reduced loss associated with lasalocid treatment is approximately NZ $\$ 1,200$. The total additional gross benefit of lasalocid feeding is thus approximately NZ $\$ 3,800$ for the herd. The cost of treatment per cow is likely to be approximately NZ $\$ 0.04 / \mathrm{d}$. For $150 \mathrm{~d}$ of treatment, the gross treatment cost is NZ $\$ 1,610$. The net benefit is 
thus approximately NZ $\$ 2,190$. Even if the treatment costs were to double, the milk payment to halve, or the production response was half of that found in the current study, the return would still be positive.

The study was not blinded as herd managers or staff undertook the oral treatment of the cows on a daily basis and the cows were clearly identified by different color neckbands. Thus, it is a possibility that herd owners were biased in terms of diagnosis or recording of disease data. However, the herd owners were not informed before the study that disease data was to be collected, nor were they informed that there was previous data suggesting that monensin treatment was associated with reduced disease incidence rate. Additionally, diagnosis of disease (especially mastitis) is commonly undertaken in the milking parlor. From the floor of the milking parlor, the cows' necks were not visible; hence, the cow's treatment group would not be known at the time of diagnosis. For these reasons, it is believed that bias in diagnosis or recording of disease is unlikely to have been a major confounder in this study. The relationship between lasalocid and disease has not been previously examined. The relationship between monensin treatment and disease incidence or prevalence appears to be complex as a number of studies have failed to demonstrate any change in disease incidence (Beckett et al., 1998), whereas others have demonstrated a reduced incidence or prevalence of some diseases with ionophore treatment (Duffield et al., 1999b; Heuer et al., 2001). Inconsistent results among studies may partly be explained by limitations of the size of the studies and the possibility that type 2 errors (i.e., failure to declare a true difference) were occurring. For example, in the present study, there were 9 (among 516 cows) and 6 (among 504 cows) cases of lameness in the control and lasalocid groups, respectively, an apparent $30 \%$ decline due to treatment. However, to demonstrate statistical significance between a prevalence of 1.2 and $1.7 \%$, more than 9000 cases per treatment group would be required.

The incidence rate of clinical mastitis was reduced in lasalocid-treated compared with control cows in the present study. A reduced risk of subclinical mastitis has been reported in monensin-treated cows (Heuer et al., 2001). However, mastitis incidence rate was not decreased in other monensin studies (Beckett et al., 1998; Duffield et al., 1999b). It has been demonstrated that metabolic status can affect clinical mastitis as ketosis is positively related to probability of diagnosis of clinical mastitis (Suriyasathaporn et al., 2000). Elevated BHBA concentrations reduce chemotaxis (Suriyasathaporn et al., 1999) and monensin treatment improves chemotaxis (Stephenson et al., 1996). Hence, changes to intermediate metabolism associated with monensin treatment may improve immune function and hence reduce the likelihood of clinical mastitis. However, in the current study, no differences in BHBA concentration were found between lasalocid and control cows; therefore, another mechanism by which lasalocid influences mastitis incidence may exist.

The proportion of cows presented for veterinary examination because they had not been detected in estrus was lower in lasalocid-treated vs. control cows in 1 herd. Heuer et al. (2001) reported a shorter interval from calving to first service and from calving to conception for monensin-treated cows with endometritis, which supports the finding of the present study. However, a number of other studies have failed to demonstrate improvements in reproductive performance in pasture or more intensively fed cattle (Lean et al., 1994; Hayes et al., 1996). Differences in feed intake, feed quality and quantity, partitioning, and/or genetics and the possibility of type 2 errors may explain this disparity among studies. The postpartum anestrous interval is associated with a nadir in energy balance, and NEFA concentration is correlated with energy balance (Canfield and Butler 1991). Additionally, the probability of expression of behavioral estrus at first postpartum ovulation is increased where the glucose to plasma 3-hydroxybutyrate ratio is elevated (Westwood et al., 2002). Hence the increased gluconeogenesis (Richardson et al., 1976) and reduced BHBA levels associated with monensin feeding (Duffield et al., 1998b; Heuer et al., 2001) may lead to improved nutrition and hence positive effects on reproductive performance.

\section{CONCLUSIONS}

This study demonstrated a small but significant increase in milk production (both milk fat and protein), a reduction in the prevalence of undetected estrus, and reduced incidence rate of clinical mastitis in dairy cattle following lasalocid treatment. The increase in productivity occurred without increased mobilization of body tissue, as assessed by BCS, relative to untreated controls.

\section{ACKNOWLEDGMENTS}

The cooperation of the herd owners in this study is gratefully acknowledged. A. Bouma and H. Habgood are thanked for their veterinary and technical assistance, respectively. H. Henderson and C. Heuer are thanked for statistical discussions related to this study.

\section{REFERENCES}

Abe, N., I. J. Lean, A. Rabiee, J. Porter, and C. Graham. 1994. Effects of sodium monensin on reproductive performance of dairy cattle. 
II. Effects on metabolites in plasma, resumption of ovarian cyclicity and oestrus in lactating cows. Aust. Vet. J. 71:277-282.

Bauman, D. E., and W. B. Currie. 1980. Partitioning of nutrients during pregnancy and lactation: A review of mechanisms involving homeostasis and homeorhesis. J. Dairy Sci. 63:1514-1529.

Beckett, S., I. Lean, R. Dyson, W. Tranter, and L. Wade. 1998. Effects of monensin on the reproduction, health, and milk production of dairy cows. J. Dairy Sci. 81:1563-1573.

Bergen, W. G., and D. B. Bates. 1984. Ionophores: Their effect on production efficiency and mode of action. J. Anim. Sci. 58:1465-1483.

Broster, W. H., V. J. Broster, and A. J. Clements. 1993. Feed utilization by the dairy cow over multiple lactations: A review. Livest. Prod. Sci. 34:1-21.

Canfield, R. W., and W. R. Butler. 1991. Energy balance, first ovulation and the effects of naloxone on LH secretion in early postpartum dairy cows. J. Anim. Sci. 69:740-746.

Duffield, T. F., K. E. Leslie, D. Sandals, K. Lissemore, B. W. McBride, J. H. Lumsden, P. Dick, and R. Bagg. 1999a. Effect of prepartum administration of monensin in a controlled-release capsule on milk production and milk components in early lactation. J. Dairy Sci. 82:272-279.

Duffield, T. F., K. E. Leslie, D. Sandals, K. Lissemore, B. W. McBride, J. H. Lumsden, P. Dick, and R. Bagg. 1999b. Effect of a monensincontrolled release capsule on cow health and reproductive performance. J. Dairy Sci. 82:2377-2384

Duffield, T. F., D. Sandals, K. E. Leslie, K. Lissemore, B. W. McBride, J. H. Lumsden, P. Dick, and R. Bagg. 1998a. Effect of prepartum administration of monensin in a controlled-release capsule on postpartum energy indicators in lactating dairy cows. J. Dairy Sci. 81:2354-2361.

Duffield, T. F., D. Sandals, K. E. Leslie, K. Lissemore, B. W. McBride, J. H. Lumsden, P. Dick, and R. Bagg. 1998b. Efficacy of monensin for the prevention of subclinical ketosis in lactating dairy cows. J. Dairy Sci. 81:2866-2873.

Edmonson, A. J., I. J. Lean, L. D. Weaver, T. Farver, and G. Webster. 1989. A body condition scoring chart for Holstein-Friesian dairy cows. J. Dairy Sci. 72:68-79.

Erasmus, L. J., I. Smith, A. Muller, and D. O'Hagan. 1999. Effects of lasalocid on performance of lactating dairy cows. J. Dairy Sci. 82:1817-1823.

Gordon, F. J., and C. H. McMurray. 1979. The optimum level of protein in the supplement for dairy cows with access to grass silage. Anim. Prod. 29:283-291.

Hanson, T. L., and T. J. Klopfenstein. 1979. Monensin protein source and protein levels in growing steers. J. Anim. Sci. 48:474-479.

Hayes, D. P., D. U. Pfeiffer, and N. B. Williamson. 1996. Effect of intraruminal monensin capsules on reproductive performance and milk production of dairy cows fed pasture. J. Dairy Sci. 79:1000-1008.

Heuer, C., Y. H. Schukken, L. J. Jonker, J. I. D. Wilkinson, and J. P. T. M. Noordhuizen. 2001. Effect of monensin on blood ketone bodies, incidence and recurrence of disease and fertility in dairy cows. J. Dairy Sci. 84:1085-1097.

Hintze, J. 2001. Number cruncher statistical systems. Available: www.ncss.com. Accessed July 16, 2004.

Johnson J. C., P. R. Utley, B. G. Mullinix, and A. Merrill. 1988. Effects of adding fat and lasalocid to diets of dairy cows. J. Dairy Sci. 71:2151-2165.

Kolver, E. S., and K. L. Macmillan. 1994. Variation in selected blood plasma constituents during the post-partum and breeding periods in dairy cows. N. Z. Vet. J. 42:161-166.

Lean, I. J., M. Curtis, R. Dyson, and B. Lowe. 1994. Effects of sodium monensin on reproductive performance of dairy cattle. I. Effects on conception rates, calving-to-conception intervals, calving-toheat and milk production in dairy cows. Aust. Vet. J. 71:273-277.

Lobley, G. E., A. Connell, M. A. Lomax, D. S. Brown, E. Milne, A. G. Calder, and D. A. H. Farningham. 1995. Hepatic detoxification of ammonia in the ovine liver: Possible consequences for amino acid catabolism. Br. J. Nutr. 73:667-685.

Lowe, L. B., G. J. Ball, V. R. Carruthers, R. C. Dobos, G. A. Lynch, P. J. Moate, P. R. Poole, and S. C. Valentine. 1991. Monensin controlled-release intraruminal capsule for control of bloat in pastured dairy cows. Aust. Vet. J. 68:17-20.

Lynch, G. A., M. E. Hunt, and S. N. McCutcheon. 1990. A note of the effect of monensin sodium administered by intraruminal controlled-release devices on productivity of dairy cows at pasture. Anim. Prod. 51:418-421.

McBride, B. W., and J. M. Kelly. 1990. Energy cost of absorption and metabolism in the ruminant gastrointestinal tract and liver: A review. J. Anim. Sci. 68:2997-3010.

Macdonald, K. A., and K. L. Macmillan. 1993. Condition score and liveweight in Jersey and Friesian cows. Pages 47-50 in Proc. Ruakura Farmers Conf. AgResearch, Hamilton, New Zealand.

Poos, M. I., T. L. Hanson, and T. J. Klopfenstein. 1979. Monensin effects on diet digestibility, ruminal protein bypass and microbial protein synthesis. J. Anim. Sci. 48:1516-1524.

Rhodes, F. M., S. McDougall, C. R. Burke, G. A. Verkerk, and K. L. Macmillan. 2003. Treatment of cows with an extended postpartum anoestrous interval. J. Dairy Sci. 86:1876-1894.

Richardson, L. F., A. P. Raun, E. L. Potter, C. O. Cooley, and R. P. Rathmacher. 1976. Effect of monensin on rumen fermentation in vitro and in vivo. J. Anim. Sci. 43:657-664.

Rosenberger, G. 1979. Page 125 in Clinical Examination of Cattle. Verlag Paul Parey, Berlin, Germany.

Sauer, F. D., J. K. Kramer, and W. J. Cantwell. 1989. Antiketogenic effects of monensin in early lactation. J. Dairy Sci. 72:436-442.

Stephenson, K. A., I. J. Lean, M. L. Hyde, M. A. Curtis, J. K. Garvin, and L. B. Lowe. 1997. Effects of monensin on the metabolism of periparturient dairy cows. J. Dairy Sci. 80:830-837.

Stephenson, K. A., I. J. Lean, and T. J. O'Meara. 1996. The effect of monensin on the chemotactic function of bovine neutrophils. Aust. Vet. J. 74:315-317.

Stevenson, M. A., N. B. Williamson, and D. J. Russell. 2003. Nutrient balance in the diet of spring calving, pasture-fed dairy cows. N. Z. Vet. J. 51:81-88.

Suriyasathaporn, W., A. J. J. M. Daemen, E. N. Noordhuizen-Stassen, S. J. Dieleman, M. Nielen, and Y. H. Shuckken. 1999. BetaHydroxybutyrate levels in peripheral blood and ketone bodies supplemented in culture media affect the in vitro chemotaxis of bovine leukocytes. Vet Immunol. Immunopathol. 68:177-186.

Suriyasathaporn, W., C. Heuer, E. N. Noordhuizen-Stassen, and Y. H. Shuckken. 2000. Hyperketonemia and the impairment of udder defense: A review. Vet. Res. 31:397-412.

Van der Werf, J. H., L. J. Jonker, and J. K. Oldenbroek. 1998. Effect of monensin on milk production by Holstein and Jersey cows. J. Dairy Sci. 81:427-433.

Weaver, A. D., L. Andersson, A. de Laistre Banting, P. N. Demerzis, P. F. Knezevic, D. J. Peterse, and F. Sankovic. 1981. Review of the disorders of the ruminant digit with proposals for anatomical and pathological terminology and recording. Vet. Rec. 108:117120.

Weiss, W. P., and B. A. Amiet. 1990. Effect of lasalocid on performance of lactating dairy cows. J. Dairy Sci. 73:153-162.

Westwood C. T., I. J. Lean, and J. K. Garvin. 2002. Factors influencing fertility of Holstein cows: A multivariate description. J. Dairy Sci. 85:3225-3237. 